\title{
THE DEVELOPMENT OF READING LEARNING MATERIAL BASED ON DRTA STRATEGY AS AN EFFORT TO BUILD A LITERATE GENERATION IN FIFTH GRADE $\left(5^{\text {th }}\right.$ OF PRIMARY SCHOOL
}

\author{
Faisal, Stelly Martha Lova
}

Surel: faisalpendas@gmail.com

\begin{abstract}
This study aims to develop reading learning materials based on DRTA strategy (Direct Reading Thinking Activity) as an effort to build a literate generation in $5^{\text {th }}$ Grade of Primary School. It is well known that the literacy study is one part of the implementation policy of the 2013 curriculum in primary school. This policy implies that the learning process implemented so far has not been able to adopt the optimal process of literacy learning. There are three main requirements to be considered in the development research conducted, such as; the validity, practicality and effectiveness of teaching materials developed. The development model used is a 4-D model, namely: define, design, development and disseminate. The results showed that the developed teaching materials declared were valid, practical and effective to use in the reading learning process of $5^{\text {th }}$ grade in Primary School. Thus, the use of DRTA-based teaching materials in reading learning deserves to be considered as an effort to build literate generation in $5^{\text {th }}$ Grade of Primary School.
\end{abstract}

Keywords: teaching material, reading, DRTA Strategy, literate generation

\section{INTRODUCTION}

Bahasa Indonesia Learning in Primary School contains four language skills: listening, speaking, reading, and writing. The first two skills are the language skills covered by oration, while the second skills are skills covered by literacy. The ability of speech is an ability related to spoken language, while literacy ability is related to written language. Among the four skills expressed, one of the main concerns is reading skills. According to Somadayo (2011:1) reading is one of the most important language skills in addition to the other three language skills.

Reading means to learn something to expand knowledge and dig up written messages in reading material. Another view is also explained by Klingner (2007:2) that "Reading is the process of constructing meaning by coordinating a number of complex processe that include word reading, word and word knowledge, and fluence." In the concept of literacy, reading learning is the ability to associate with written discourse as a representation of experience, thoughts, feelings and ideas appropriately according to the goal.

Related to the literate generation, UNESCO provides a description of a literate person is if he/she has essential knowledge to be used in any activity that demands effective literacy functions in society. Then, the knowledge 
Faisal, Stelly Martha Lova : The Development Of Reading ...

achieved by reading allows it to be used for people himself/herself and

the development of society. Furthermore, Stone (2009:20) explains that to be a true literate generation, one must have the ability to use different types of texts appropriately and the ability to empower thoughts, feelings, and actions in the context of social activities with a specific purpose.

Responding to the above statements, the process of reading learning should pay attention to the proper stages in the implementation. This is done because the contents of each subject matter can be explored and understood well through the good and right reading activities. One of the efforts to create a good and right reading activity can be achieved through a well-structured reading material that is oriented towards the right learning strategy. Teaching materials developed with the right strategy will foster creative effort of self discovery of reading contents by students. The process of discovery, in addition to recognize the type of text to be read can also be done by predicting and summarizing the content of the readings

appropriately. The activities expressed will certainly provide a meaningful learning experience for students in reading. The experience will be visible when the student is able to understand the content of the reading and absorb the information from the material he/she reads intactly. As mentioned earlier, that kind of ability that can be expressed as an indicator of literate generation in primary school. Therefore, the readiness of teaching materials is one of the determinants of the success or the failure of reading process in primary school.

Based on the observations and interviews of the authors with the teacher of $5^{\text {th }}$ grade SD Negeri 10 Lembah Melintang Pasaman Barat, reading learning material has not been developed optimally. Teaching materials developed are less direct students on the stages of learning to read correctly, namely pre-reading, reading, and post-reading. Therefore, the teaching materials used can not describe an effective learning process of reading in an effort to build literate generation in primary school. The process of reading learning that has not been effective can be seen in the less directed students to predict the title of reading that will be read. It is known that making predictions about the title of reading is the first step that can determine students' understanding of the reading content that will be read. Then, the guidance in summarizing the contents of reading material is also less done maximally so that the resulting summary does not include all the contents of reading material.

Overcoming the problems presented above, teachers should be able to develop the reading learning materials effectively and creatively. Furthermore, to be more targeted in its use, the developed learning materials should use appropriate strategies with reading skills. One of 
the strategies that can be used in effective reading learning is Directed Reading Thinking Activity (DRTA) strategy. According to Staufer (in Rahim, 2007:47), the DRTA strategy is a strategy that focuses on students' engagement with reading texts because students predict reading content and prove it when they read. This indicates that the DRTA strategy directs the students' active role in finding their own reading content. In addition, this strategy can train students to concentrate and think in understanding the content of the reading seriously.

DRTA strategy has structured and systematic stages in its application. According to Tomkins and Hoskisson (1991:285) there are three stages of the DRTA strategy, namely: (1) Predicting: after showing students the cover of the book and reading the title the teacher begins by asking students to make a prediction about the story using question, (2) reasoning and predicting from succeeding pages: after setting their purpose for reading the students or teacher read part of the story and students begin to confirm or reject their prediction, and (3) proving: students give reasons to support predictions by writing answers to questions.

The implementation of DRTA strategy in reading learning will be able to help students to understand the whole reading content through prediction and proof of prediction. After proving the prediction, students can take the conclusion by accepting or rejecting the prediction. According to Resmini and Dadan Juanda (2007:94), the DRTA strategy can engage students intellectually and encourage them to formulate questions or hypotheses, process, and then evaluate temporary solutions. This illustrates that the DRTA strategy is one of the reading strategies that focus on students' involvement to the reading material thoroughly.

Looking at the above explanation, it is necessary to do a development research in the form of development of teaching materials based on DRTA strategy in order to streamline the process of reading learning in the classroom. The way is by combining the stages contained in DRTA strategy with the stages in reading learning. Thus, the learning material will be developed as a reading material based on DRTA strategy.

The term research development is a simplification of the term Research and Development (R \& D). According to Setyosari (2010:194), it is said to be a development research because this research is often regarded as "Research Based Development" so it is commonly abbreviated as development research. Furthermore, Trianto (2011:243) explains that development research is a research conducted to develop a product or improve a particular product. In the development undertaken, the product needs to be tested to see the effectiveness of its use. Sugiyono 
Faisal, Stelly Martha Lova : The Development Of Reading ...

(2011:407) states that the concept of development research is a research method used to produce a specific product and to test the effectiveness of the product.

Based on the explanation above, there are three main requirements that must be considered in development research, namely:

validity, practicality and effectiveness of the resulting product. Associated with validity, Otto (2010:348) explains validity refers to the notion that the best actually measures what it is intended to measure. This means that the best items or tasks are carefully selected to represent key developmental

milestones and behavior." Associated with practicality, Akker, et al (1999:10) explains ppractically refers to the extent that user (or other expert) consider the intervention as appealing and usable in 'normal'

conditions". With regard to effectiveness, Akker, et al (1999:10) give explanation that eeffectiveness refers to the extent that the experiences and outcomes with the intervention are consistent with the intended aims. According to the three main requirements of the above

development research, the formulation of problems that can be developed in this research are: "How is the validity, practicality and effectiveness of reading materials based on DRTA strategy as an effort to build literate generation in $5^{\text {th }}$ Grade of Primary School?.

\section{RESEARCH METHOD}

This research is a development research or often called as R \& D (Research and

Development). Research development is designed in a structured and systematic way to develop teaching materials through certain stages and evaluations to test the level of validity, practicality and effectiveness. The development model used is a 4-D development model (four D models). In this case, Sugiyono (2011:404) explains that there are 4 stages in the 4-D model, namely: define, design, development and disseminate. The stages described can be seen in chart 1 below. 


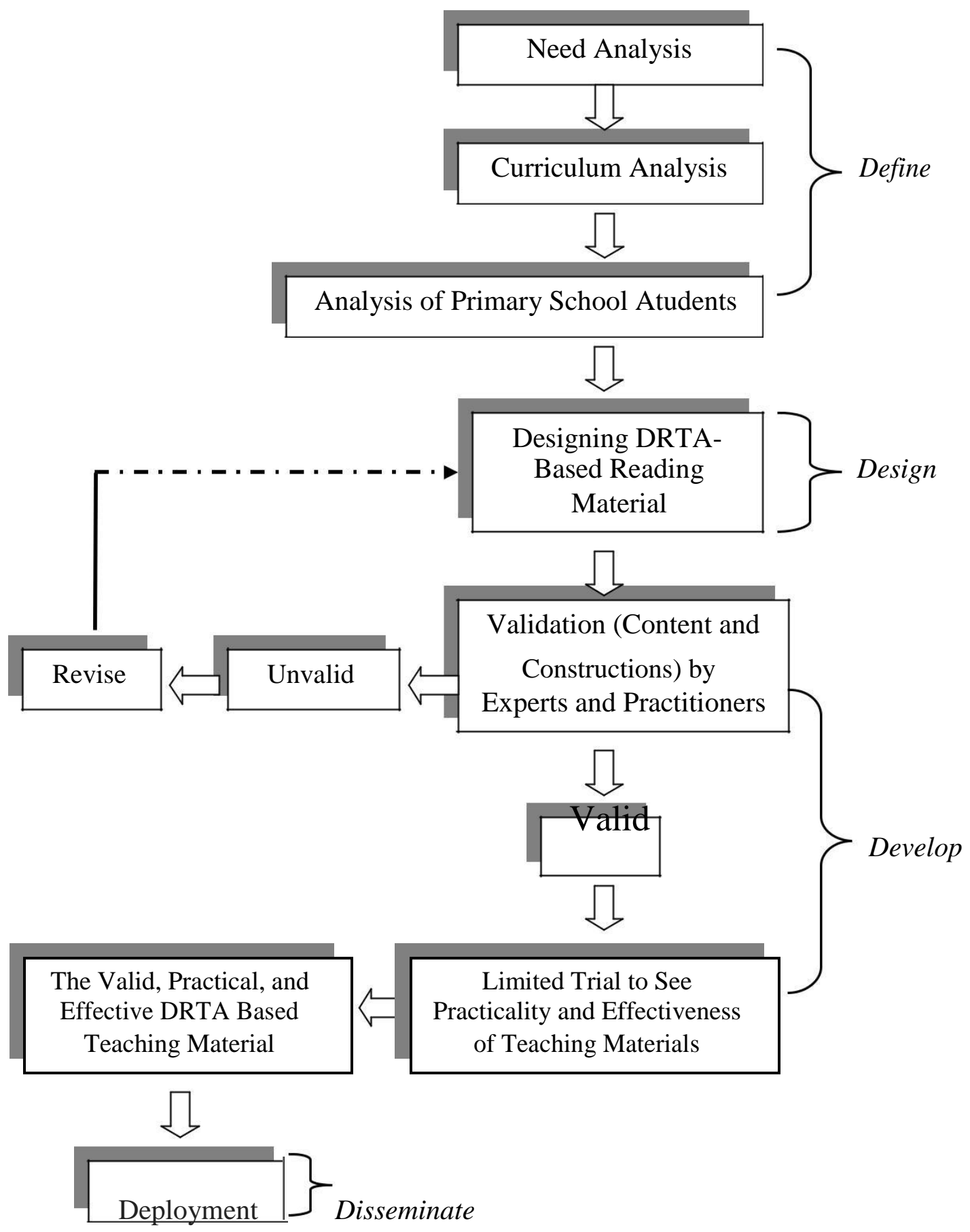

Figure 1. Scheme of the Development of Reading Teaching Material Based on DRTA-Based Strategy in $5^{\text {th }}$ Grade of Primary School

The definition stage is the step of determining the learning conditions in accordance with the purpose of development, including:

(1) Needs analysis, which is the analysis of teaching materials by looking at various weaknesses and shortages of teaching materials that have been developed previously. The shortcomings and weaknesses are then revised, improved, and developed in accordance with the

p-ISSN : 2355-1720

e-ISSN`: 2407-4926

p-ISSN : 2355-1720

e-ISSN ${ }^{`}$ : 2407-4926 
needs of the learning process to read effectively in $5^{\text {th }}$ grade of Primary School; (2) Curriculum analysis, including analysis of $\mathrm{KI}$ and $\mathrm{KD}$, concepts contained in $\mathrm{KI}$ and $\mathrm{KD}$, as well as tasks that can be developed in achieving KI and KD; (3) Student analysis, is a study of the characteristics of students relating to the level of development of acquired language, reading skills and other knowledge background.

The design stage is the design stage of reading learning materials based on DRTA strategy in in $5^{\text {th }}$ grade of Primary School based on the previous definition. There are several aspects that need to be considered in designing instructional materials, among others: (A) Conformity of materials with curriculum (KI and KD); (B) Selection of learning resources

(preferably selected text in accordance with the conditions of

students in the immediate environment), (C) Determination of the order of reading learning process in accordance with the DRTA strategy: pronunciation, reading and post-reading, (D) Material conformity with the time (E) the grammar used (the level of readability of texts should be easy to understand), and (F) The way in which the material is presented should follow the effective stage of reading.

The development stage is to produce revised teaching materials based on the experts' input. If the developed subject has not been valid yet, it needs to be revised according to the validator's suggestion. If the material is valid, a trial is done to see the effectiveness and effectiveness of the developed teaching materials.

The type of data taken in this study was data validity, practicality and the effectiveness of teaching materials developed. The results of validity were obtained through the assessment of expert and education practitioners. Data obtained for practicality are: (1) observation result of teaching materials from observer, (2) observation of student activity from observer, (3) student response to teaching material developed after tested, and (4) teacher response to developed teaching material after tested, while the data of reading effectiveness is obtained through the activity and result of students' reading skill improvement.

The data of validity, practicality, and effectiveness obtained were then analyzed on each component. For more details can be seen in the following explanation:

\section{Validity data analysis}

Data of validation result of instructional materials was obtained and analyzed to all aspect presented by using Likert scale with value range from 1 to 4 , then searched average value by using the following formula (Faisal, 2015:8).

$\mathbf{R}=\frac{\sum_{\mathrm{i}=1}^{\mathrm{n}}}{\mathrm{nm}}$ 
Information:

$\mathrm{R}$

: Average assessment results from experts / practitioners

Vij : Score of the experts' assessment

$\mathrm{N} \quad$ : Number of experts / practitioners who assess

M : Number of criteria

The average earned is confirmed by the specified criteria.

Widjajanti (2008:58) provides procedures for determining the level of validity with criteria such as table 1 below.

Table 1. Criteria for Establishing Validity Levels

\begin{tabular}{c|l}
\hline \multicolumn{1}{c|}{ Range } & \multicolumn{1}{c}{ Category } \\
\hline $1,00-1,99$ & Invalid \\
\hline $2,00-2,99$ & Less Valid \\
\hline $3,00-3,49$ & Valid \\
\hline $3,50-4,00$ & Very Valid \\
\hline
\end{tabular}

\section{Practical Data Analysis}

Practical analysis is used to process the results of observation of the use of teaching materials, student response questionnaires, teacher

response questionnaires and interview results of the use of teaching materials. Similar to validity, the level of practicability is also converted into rubrics scores 1 -

4. The observed data were analyzed by using descriptive qualitative statistic with the provisions as in table 2 below.
Table 2. Criteria for Establishing Practicality Level

\begin{tabular}{c|l}
\hline \multicolumn{1}{c|}{ Range } & Conversion \\
\hline $1,00-1,99$ & L ess practical \\
\hline $2,00-2,99$ & Practical Enough \\
\hline $3,00-3,49$ & Practical \\
\hline $3,50-4,00$ & Very Practical \\
\hline
\end{tabular}

\section{Effectiveness Data Analysis}

The result data of observation sheet and reading skill activity were analyzed by the percentage calculation using formula developed from the basic concept of evaluation of learning result (Arikunto, 2006:233) as follows.

Percentage =

Frequency of student activity performed $\times 100 \%$

the number of students

Based on the percentage obtained, the grouping was done according to the criteria stated by Arikunto (2006:166) in table 3 below.

Table 3. Criteria for Determining Effectiveness Level

\begin{tabular}{c|l}
\hline $\begin{array}{c}\text { Percentage } \\
(\boldsymbol{\%})\end{array}$ & $\begin{array}{l}\text { Criteria of } \\
\text { Activity }\end{array}$ \\
\hline $81-100$ & Excellent \\
\hline $61-80$ & Good \\
\hline $41-60$ & Enough \\
\hline $21-40$ & Less \\
\hline $1-20$ & Very Less \\
\hline
\end{tabular}

\section{RESEARCH RESULTAND DISCUSSION}

The result of this research is the development of reading materials based on DRTA strategy which is valid, practical and effective in $5^{\text {th }}$ 
Grade of Primary School. The teaching materials have been tested in $5^{\text {th }}$ Grade of SD Negeri 10 Lembah Melintang with 24 students and also conducted in $5^{\text {th }}$ Grade of SD Negeri 8 Lembah Melintang with 25 students. For more details will be described as follows.

\section{Material Validity}

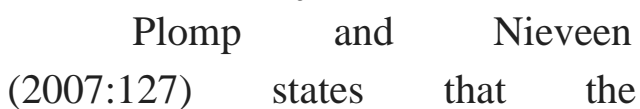
characteristic of the valid teaching materials is when it reflects the soul of knowledge (state of the art knowledge). This is also known as content validation. Furthermore, the components of the developed teaching materials must also be consistent with each other and this is also known as construct validation (construct validity). Therefore, validation of learning materials based on reading DRTA strategy emphasizes content validity and construct validity.

The result of the validation of teaching material analysis was obtained an average value of 3.84 with very valid category. Therefore, the teaching materials developed are in accordance with the curriculum demands and the process of the effective reading learning in $5^{\text {th }}$ grade of primary school. The presentation of the material has been in accordance with the formulation of indicators and characteristics of $5^{\text {th }}$ grade of primary school students.

The various concepts and elaborations of the tasks contained in the teaching materials make the students easier to understand the content of the text correctly. The content of the teaching materials has been able to achieve the selected basic competencies. In addition, the use of language in teaching materials using simple and clear sentences, so it is easily understood by students. The sentences use the correct spelling. Then, the materials that have been developed are designed with an attractive color, so that it can motivate students to follow the learning process well. Thus, it can be seen that reading materials based on the DRTA strategy present the various reading activities effectively in $5^{\text {th }}$ grade of primary school.

\section{The Practicality of Teaching Materials}

Plomp and Nieveen (2007:127) explain that teaching materials are said to be practical if teaching materials can be used easily by teachers and students in the learning process. To know whether the instructional materials developed are practical or not, a test was done to the $5^{\text {th }}$ grade students of SD Negeri 10 Lembah Melintang Pasaman Barat.

Referring to the teaching materials that have been developed, learning activities were conducted in one meeting with time allocation of 4 $\mathrm{x} 35$ minutes. The level of practicability was observed through observation of the use of teaching materials, teachers' response questionnaires, students' response questionnaires and interview results on the ease of use of teaching 
materials. For more details can be seen in the following.

\section{Observation Result of the Use of Teaching Materials}

The intended observation of the use of teaching materials was whether the students are easy or not in using reading materials based on DRTA strategy developed. Based on the observation results, it is obtained the fact that students find it is easy to use teaching materials developed. Students are helped to easily understand the various concepts and steps of activities that exist in teaching materials. In addition, the designs of interesting materials make students interested and enthusiastic in doing various tasks given in the teaching materials. Thus, reading materials based on the DRTA strategy can help students to understand the reading material as a whole.

\section{Results of Teacher Response Data Analysis}

The results of the teacher response analysis provide a positive outcome or in terms of getting a positive response. This can be seen from the answer distribution of teachers earned an average of 3.74 with very practical category. From the distribution of the answers, in general the teacher stated that the developed teaching materials can help teachers in optimizing the process of learning to read effectively. Then, the activity sheets provided in the teaching materials are very helpful for students to understand the contents of the reading intact. Thus, based on the data obtained, reading materials based on DRTA strategy is very easy to use in the process of reading learning in $5^{\text {th }}$ grade of primary school.

\section{Results of Student Response Data Analysis}

The results of the student response analysis indicate that the students become more easily to understand the contents of the reading intact. The developed teaching materials are also interesting for students because they are designed with more attractive colors and adapted to the

characteristics of student development. This can be seen from the results of student responses that the teaching materials are practically used in the learning process. Students argue that the readability of teaching materials is clear and easy to understand. The average obtained is 3.38 with the practical category. This means that students feel helpful in understanding the contents of the reading in full through the stages of the learning process presented in the teaching materials.

\section{Interview Result of Use of Teaching Material}

The efforts to strengthen the practicability data of teaching material were conducted by the further interviews with teachers. The interviews conducted are unstable interviews which mean that the question develops in accordance with 
the previous teacher's answer. Based on the distribution of teachers' answers, it is illustrated that the teaching materials developed are very easy to use in the learning process. Teachers feel helpful in giving the reading material to the students because the more detailed and clear stages described in comprehending the contents of the reading as a whole. Thus, it can be concluded that reading materials based on the DRTA strategy that has been developed is easy to use and greatly helps the learning process of reading effectively in $5^{\text {th }}$ grade of primary school.

\section{The Effectiveness of Teaching Materials}

The valid and practical teaching materials need to be seen its effectiveness in the learning process of reading. According to Firman (2010:56), the effectiveness of a learning program is characterized by the following characteristics: (a) succeeds in delivering the students to achieve the stated instructional goals, (b) providing an attractive learning experience, involving students actively to achieve the instructional goals, and (c) having the means to support the learning process.

Based on the above explanation, the effectiveness of teaching materials based on DRTA strategy can be seen through the assessment of activity and the result of students' reading skill. Associated with learning activities, Permendikbud No. 41 year 2007 aboutstandardprocessfor elementary education unit explains that teaching materials are effective if students do activities with good category. Furthermore, Abidin (2012:278) explains that reading skills are effective if students get classical mastery $\geq 75 \%$. For more details can be seen in the following.

\section{Results of Student Activity Observation}

Student activity based on observation obtained an average score of $81.56 \%$ with very good category. The results are obtained

from the various activities undertaken by students in following process of reading learning, those are: pay attention and listen to the teacher's explanation well, pay attention to the teaching materials well, doing the activities steps contained in the teaching materials well and ask questions well. However, there are activities that need to be further optimized by the teacher in the learning process, for example, the difficulty of the students in responding to problems in the text reading when the teachers asked the opinion. This problem arises because students are seldom to be trained to give opinion in the learning process. Nevertheless, it is generally seen that students can demonstrate an increase in positive activity based on the utilization of developed teaching materials.

Based on the explanation above, it can be concluded that the student activity in following the reading learning strategy DRTA based on the category is very good. 
This can be seen from the enthusiasm of students in following the activities contained in the teaching materials and instructions presented by the teacher. Thus, by looking from the student activities, teaching materials have been effectively done in $5^{\text {th }}$ grade of primary school with a very good category.

\section{Reading Skills Assessment}

The effectiveness of reading skills can be seen through the assessment of reading skills. This assessment was done by considering two aspects, namely the assessment of the process and results. Process assessment is an assessment of the activity of each student in working on various activities sheets that have been provided. By this assessment, it is seen a comprehensive picture of the process that students do in comprehending the contents of the reading as a whole. Result assessment is an assessment of students' understanding in reading material afterward. Students are directed to do evaluation questions related to reading material.

\section{Assessment of Reading Skills Process}

Process assessment was done by looking at the overall reading stage, the pre-reading stage, reading stage and post-reading stage. At the pre-reading stage, students are directed to predict the content of the reading. At the reading stage, there are three aspects that are assessed, those are filling the meaning of words that have not understood yet, testing the prediction and responding to information from the text. Then, at the post-reading stage, students are directed to summarize the content of the reading coherently and intactly.

At the pre-reading stage, students can predict the text content with very good category. That means, students did not get a meaningful obstacle when they were directed to predict the contents of text reading. They were able to fill out and answer any questions contained in the activity sheets provided, although there were some inappropriate answers. However, in general at the pre-reading stage, especially in predicting the contents of the reading can be done with the maximum and in accordance with the expected results

At the reading stage, students can fill in the meaning of words that they did not understand well, although there were some students who have not been able to fill in completely. To overcome it, students are given the freedom to ask questions related to the meaning of words that have not understood. Prediction testing activities can work well too. Students can prove the truth of the prediction they have done before to get a true picture of the text. Furthermore, there was a decline in the activity of responding to information from the text read. Students give a less clear response so it was hard to understand what they mean. Many students asked questions, but they can not respond adequately to the issues raised. 
However, this aspect can be said to work well. This is stated by looking at the results of the observation sheet that the activities responding to information from the text read were categorized into the good category.

At the post reading stage, students can summarize well. The contents of the summary can be arranged in a coherent manner and the contents can give a full picture of the text content. Nevertheless, there is a key point to note in this activity, namely the use of the spelling of the summary that has been written still need further guidance. Thus, not only content and demands are concerned, but spelling accuracy also can support the effectiveness of the given summary.

By looking at the exposure of the three stages above, it can be concluded that the use of teaching materials developed can support the maximum learning activities. The

average obtained based on observations was $87.65 \%$ with very high category which mean that the students can go through the stages or process activities in each step well. Thus, in general, the processes of activities through by students get a very good average.

\section{Assessment of Reading Skills Result}

Assessment of reading skills was done by looking at how far the students can understand the content of the reading intact. Students were directed to answer evaluation questions related to reading texts. From the description of the results obtained, it was seen the exhaustiveness individually and classical. The exhaustiveness individually sees the boundaries of the KKM value set by the school, while the classical one is said to be effective when it has reached $\geq 75 \%$. Based on the observation of students' reading skill, it was achieved an average score of 82.34 with classical exhaustiveness as $86 \%$. Thus, it can be said that the use of reading materials based on strategy DRTA as an effort to build literate generation already effective used in $5^{\text {th }}$ grade of primary school.

\section{CONCLUSIONS}

Based on the research results related to the development of reading learning materials based on DRTA strategy as an effort to build literate generation in $5^{\text {th }}$ grade of primary school were obtained several conclusions:

a. A valid reading material has been produced based on DRTA strategy as an effort to build a literate generation in $5^{\text {th }}$ grade of primary school. This was obtained from the validation of teaching materials by expert validators and education practitioners with very valid category.

b. A practical reading material has been produced based on DRTA strategy as an effort to build a literate generation in $5^{\text {th }}$ grade of primary school. This means that the teaching materials developed were easy to use in the process of reading learning. This was derived from the observation of 
the teaching materials implementation by teachers, teachers' responses, students' responses, observation results and interview results. These results provide an overview that reading materials based on the DRTA strategy developed were very easy to use by teachers and students both in the process of effective reading learning in $5^{\text {th }}$ grade of primary school.

c. An effective reading material has been produced based on DRTA strategy as an effort to build a literate generation in $5^{\text {th }}$ grade of primary school. It can be known through the observation of student activities and assessment of students' reading skills. The observation result of the students' activity and reading skill gives a very good result, it means that reading materials based on the DRTA strategy have been implemented effectively.

\section{REFERENCES}

Abidin, Yunus. 2012. Pembelajaran Bahasa Berbasis Pendidikan Karakter. Bandung: Refika Aditama.

Akker, Jan Van Den, dkk. 1999. Design Approaches and Tools in Education and Training. Dordrecht: Kluwer Academic Publishers.

Arikunto, Suharsimi. 2006. Prosedur Penelitian: Suatu Pendekatan Praktek. Jakarta: Rineka Cipta.

Faisal. 2015. "Pengembangan Perangkat Pembelajaran dalam Gamitan Efektivitas
Membaca Berorientasi

Strategi DRTA di Kelas VI

Sekolah Dasar". Makalah

Disajikan pada Seminar

Nasional Inovasi

Pembelajaran Berbasis Riset, Padang 30-31 Mei 2015.

Firman, Harry. 2010. Penilaian Hasil Belajar dalam Pengajaran. Bandung: FMIPA UPI.

Klingner, Janette K, dkk. 2007. Teaching Reading Comprehension to Students with Learning Difficulties. New York: Guilford Press.

Otto, Beverly. 2010. Language Development in Early Childhood. USA: Pearson Education.

Plomp, T. dan Nieveen, N. (Eds). 2007. An Introduction to Educational Design Research. Enschede: Netherlands Institute for Curriculum Development (SLO).

Rahim, Farida. 2007. Pengajaran Membaca di Sekolah Dasar. Jakarta: Bumi Aksara.

Resmini, Novi dan Dadan Juanda. 2007. Pendidikan Bahasa dan Sastra Indonesia di Kelas Tinggi. Bandung: UPI Press.

Setyosari, Punaji. 2010. Metode Penelitian Pendidikan dan Pengembangan. Jakarta: Kencana Prenada Media Group.

Somadayo, Samsu. 2011. Strategi dan Teknik Pembelajaran Membaca. Yogyakarta: Graha Ilmu. 
Faisal, Stelly Martha Lova : The Development Of Reading ...

Stone, Randi. 2009. Best Practices for Teaching Reading.

California: Corwin Press.

Sugiyono. 2011. Metode Penelitian

Pendidikan Pendidikan

Kuantitatif, Kualitatif, dan

$R \& D$. Bandung: Alfabeta.

Tomkins, Gail E dan Hoskisson,

Kenneth. 1991. Language Arts

Content and Teaching

Strategies. New York:

Macmillan Publishing

Company.

Trianto. 2011. Mendesain Model

Pembelajaran Inovatif-

Progresif. Jakarta: Kencana

Prenada Media Group.

Widjajanti, E. 2008. "Pelatihan

Penyusunan LKS Mata

Pelajaran Kimia Berdasarkan

KTSP bagi Guru SMK/MAK."

Makalah Disajikan dalam

Kegiatan Pengabdian pada

Masyarakat. Yogyakarta:

Jurusan Pendidikan Kimia

FMIPA Universitas Negeri

Yogyakarta. 